\title{
トピックス
}

\section{IV. 予後と病診連携}

\section{1. リンパ球系腫瘍の予後・予後因子}

\section{檀原 幹生 鎌田 浩稔 翁 祖誠}

要旨

悪性腫瘍の予後は大別して 3 つの要因により規定される。一つは腫瘍側の要因, 二つ目は腫瘍を担持し た宿主側の要因, そして最後に外的要因である.これらの 3 要因は疾患によって異なり，常に相互に影響 しあって存在し, 時代とともに変化する. 従って予後因子, 予後予測システムの考え方も変遷していくこ とになる．ここでは紙面に余裕のある限り，リンパ球系腫瘍の予後・予後因子に関する最近の知見を述べ てみたい.

〔日内会誌 $100 ： 1898 \sim 1908 ， 2011 〕$

\section{はじめに}

リンパ球系悪性腫瘍に限らず悪性腫瘍の予後 を規定する要因は多岐に渡るが, 3 つに大別して 考えることができよう。一つは腫瘍側の要因 : 腫瘍の量は言うまでもなく, 存在する部位, 広 がりかた，さらに重要なのは腫瘍自体が持つ生 物学的特徴，それを規定するジェネティク，ま たエピジェネティクな変容がもたらす細胞内分 子の量的, 質的異常のパターンである. 二つ目 は腫瘍を抱えた宿主側の要因である. 年歯令, 性, 人種, 主要臓器の健全さ, 免疫系の状態等が挙 げられる。これらの中には腫瘍を取り囲む正常 組織 $=$ 微小環境の特徵も含まれる. そして最後 に挙げられるのが外的要因, すなわち薬荗, 放
射線療法を含む治療体系である。

これら 3 要因は常に相互に影響しあって存在 しているため話しは非常に複雑になる。例えば 化学療法による腫瘍量の大幅な減少 $=$ 抗腫瘍効 果は当然予後を改善させるが, 宿主の, 特に腫 瘍を取り囲む微細環境に多大なる影響を与える とともに，微小に残存した腫瘍細胞の生物学的 特徵にも二次的変化を引き起こす可能性がある. これらの変化は必ずしも予後に正のインパクト を与えるとは限らない. 治療後正常な免疫系の 再構築に要する期間や, 残存した腫瘍の量のみ ならず腫瘍細胞の質的変化が再発率や再発まで の期間を規定する. 治療の反応性だけではなく, 寛解から再発までの期間が予後因子として注目 されるのもこのような理由による．このように 考えると理想的な予後予測システムの構築は困

\section{北里大学病院血液内科}

Lymphoid Malignancies : Progress in Diagnosis and Treatment. Topics : IV. Prognosis and Cooperation between Hospitals and Community Clinics ; 1 . Prognosis and prognostic factors in lymphoid malignancy.

Mikio Danbara, Hirotoshi Kamata and Sosei Okina : Department of Hematology, Kitasato University Hospital, Japan. 
表 1.JALSG-ALL93 による予後因子とRisk分類（文献 2 より 改変)

\begin{tabular}{|c|c|}
\hline Risk分類 & 6 年全生存率 (\%) \\
\hline $\begin{array}{l}\text { Low-Risk } \\
\text { 年齢 }<30 \text { 歳 かつ 白血球数 }<30,000 / \mu 1\end{array}$ & 53 \\
\hline $\begin{array}{l}\text { Intermediate-Risk } \\
\text { 年齢 }<30 \text { 歳 または 白血球数 }<30,000 / \mu \text { | }\end{array}$ & 35 \\
\hline $\begin{array}{l}\text { High-Risk } \\
\text { Ph 陽性 } \\
\text { 年齢 } \geqq 30 \text { 歳 かつ 白血球数 } \geqq 0,000 / \mu 1\end{array}$ & 15 \\
\hline
\end{tabular}

Ph : フィラデルフィア染色体

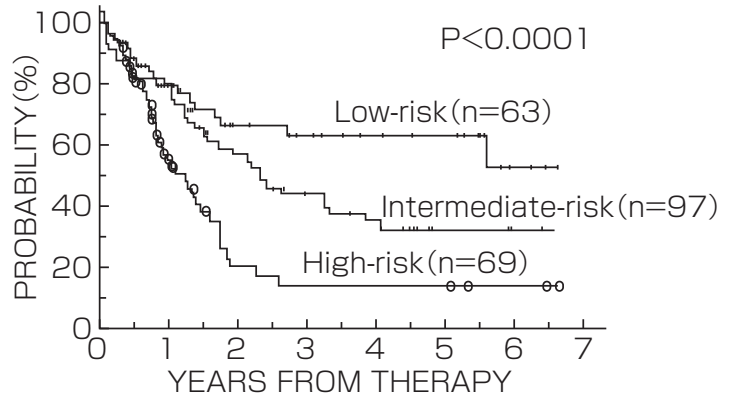

図 1.JALSG-ALL93 studyによる成人ALLの risk群別Overall survival (OS)（文献 2 より)

難を極める．分子生物学的アプローチを含む解 析技術の進歩により腫瘍の細胞生物学的特徴が 明らかになりつつあり, そして数々の新しい分 子標的治療薬が実際に臨床応用されるようになっ た現在, 予後因子, 予後予測システムも革新を 続けているのが現状である.

本稿では紙面に限りがあるため, リンパ球系 悪性腫瘍の中でも急性リンパ性白血病, 悪性リ ンパ腫, そして多発性骨髄腫を取り上げて最近 の予後因子，予後予測システムについての知見 を述べてみたい.

\section{1.急性リンパ性白血病}

小児の急性リンパ性白血病（ALL）に比べて 成人ALLの予後は悪い。その長期生存率は 60
歳未満で 30〜 40\%，60７0 歳で 10～15\%，70 歳を越えると $5 \%$ 未満と言われている ${ }^{1)}$.これま で成人ALLの予後因子として年齢, 性差, 診断 時の白血球数, 腫瘍細胞の免疫形質, 完全寛解 (CR) 達成までの期間, 中枢神経系への浸潤の有 無, HLA一致のドナーの存在, 染色体異常, minimal residual disease (MRD) の存在等, 種々な ものが指摘されてきた. 2002 年, 我が国のJapan Adult Leukemia Study Group（JALSG）は成人 ALL, 263 例に関して臨床データを解析, 3 つの 生存に寄与する予後因子：年齢, 診断時の白血 球数, フィラデルフィア染色体 $(\mathrm{Ph})$ を用いて 作成したリスクモデルを発表した ${ }^{2}{ }^{2}$ (表 1)。これ により分類されるlow risk, Intermediate risk, high risk, 3 群の 6 年Overall survival(OS) は, それぞれ $53 \% ， 35 \% ， 15 \%$ であった(図 1). 成 人ALLの 15〜20\%に陽性例を認めるPhが予後不 良因子の一つであることは間違いないが, 2000 年に入り abl tyrosine kinaseをターゲットとした 分子標的薬であるimatinibが臨床に導入されて以 来, その $95 \%$ にPhを有する慢性骨髄性白血病の 治療成績が飛躍的にあがる一方, Ph陽性ALL に関しても, imatinib併用化学療法を用いた JALSG Ph + ALL202 試験では完全宽解率 (CR) $97.0 \%, 3$ 年OS率 $58.8 \%$ と従来の報告に比べて非 常に良好な成績を示した ${ }^{3)}$. $\mathrm{Ph}$ 陽性例と $\mathrm{Ph}$ 除性例 で治療戦略が変わっていく可能性がある現在, 
表2. MRC UKALLXII/ECOG E2993による 予後因子とRisk分類（文献 4 より改変）

\begin{tabular}{c|c|c}
\hline Risk分類 & 予後因子数 & 長期全生存率 (\%) \\
\hline Low & & 55 \\
Ph- & 0 & \\
\hline Intermediate & 1 & 34 \\
Ph- & 1 & \\
Ph+ & 2 & 5 \\
\hline High & \\
Ph- & & \\
\hline
\end{tabular}

\section{予後因子}

(1)年齢 $\geqq 35$ 歳,

(2)診断時の白血球数

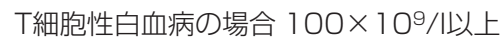

B細胞性白血病の場合 $30 \times 10 \% / \mu 1$ 以上

$\mathrm{Ph}-$ : フィラデルフィア染色体陰性, Ph+：フィラ

デルフィア染色体陽性

予後予測モデルも別個に考えるべきであろう. 1993 年, イギリスのMedical Research Council (MRC) とアメリカのEastern Cooperative Oncology Group（ECOG）は共同して, 成人ALLに対 する至適治療の確立を目指した大規模な前向き 調查 (MRC UKALLXII/ECOG E2993)を開始し た. 2005 年に彼らが報告した成人ALLの予後因 子とそれらに基づくリスク分類 ${ }^{4}$ を見ると(表 2 ), $\mathrm{Ph}$ 除性例でも 2 つの予後不良因子を有するhigh risk群は予後不良因子を 1 つしか有さないPh陽性 ALL群=intermediate riskより予後不良としてい る. その後MRC UKALLXII/ECOG E2993はALL の予後に影響を与える染色体異常を報告した ${ }^{5)}$ (表 3).11q23 に位置するMLL遺伝子が関与する 異常t $(4 ; 11)$ はOS, Event-Free Suvival (EFS) に関して独立したrisk factorと成り得なかった が, それはt $(4 ; 11)$ を有する症例では高齢, 白 血球増多を示したためであり, 白血球 $100 \times 10^{9}$ / L以下，または年齢 35 歳未満のt $(4 ; 11)$ 例で みると両者とも他のPh陰性例に比して 5 年OS が有意に低かったため, 予後不良な染色体異常 と結論している.

一方, 最近になり成人ALLの予後に影響を与
表 3. ALLにおけるPh以外の染色体異常と予後 の関係（文献 5 より改変）

\begin{tabular}{l|c}
\hline \multicolumn{1}{c|}{ 染色体異常 } & \multicolumn{1}{c}{ 予後 } \\
\hline $\mathrm{t}(4 ; 11)$ (q2 1; q23) & \\
$\mathrm{t}(8 ; 14)$ (q24.1; q32) & \\
Low hypodiploidy/ & Poor prognosis \\
near triploidy & \\
Complex karyotype & \\
\hline High hyperdiploidy & Better prognosis \\
Del (9q) & \\
\hline
\end{tabular}

$\mathrm{Ph}$ : フィラデルフィア染色体

える bcr/abl, MLL以外の分子レベルの異常が幾 つか報告されている.例えば $8 \mathrm{q} 22.3$ に位置する Brain And Acute Leukemia Cytogenetic遺伝子 （BAALC）は造血前駆細胞に発現しているが,

BAALC高発現のbcr/abl陰性, MLL陰性B細胞性 ALL（B-ALL）は治療抵抗性を示し, BAALC 低発現のB-ALLに比して 5 年OSが有意に劣って いた6. NOTCH1 またはFBXW7 のmutationによ るNOTCH1 signal pathwayの活性化は約 50\%の T細胞性ALL (T-ALL) 例に認められる。これら のmutationがT-ALLの予後に与えるインパクト は現在のところ相反するデータがでており即断 ができないが, 双方とも wild typeの場合のT-ALL の予後は不良であると言える77. 重要なのは, こ れら予後に関与する分子の詳細な解析はimatinib で成功したような有力な新規分子標的薬の開発 につながる可能性を秘めていることである.

\section{2. 悪性リンパ腫}

悪性リンパ腫はHodgkinリンパ腫（HL）と非 Hodgkinリンパ腫 (NHL) に大別される。 その予 後は各種の病型に負うところが大であるが, NHL の中でもDiffuse large B cell lymphoma （DLBCL）を中心としたaggressive lymphoma に対する予後予測システムとして確固たる評価 を得ているものがInternational Prognostic In- 
表 4. IPIとRevised IPIの比較（文献 9 より改変）

\begin{tabular}{|c|c|c|c|}
\hline リスク分類 & 予後因子数 & 4 年PFS (\%) & 4 年OS (\%) \\
\hline \multicolumn{4}{|l|}{ Standard IPI } \\
\hline $\begin{array}{l}\text { Low } \\
\text { Low-intermediate } \\
\text { High-intermediate } \\
\text { High }\end{array}$ & $\begin{array}{l}0,1 \\
2 \\
3 \\
4,5\end{array}$ & $\begin{array}{l}85 \\
80 \\
57 \\
51\end{array}$ & $\begin{array}{l}82 \\
81 \\
49 \\
59\end{array}$ \\
\hline \multicolumn{4}{|l|}{ Revised IPI } \\
\hline $\begin{array}{l}\text { Very good } \\
\text { Good } \\
\text { Poor }\end{array}$ & $\begin{array}{l}0,1 \\
2 \\
3,4,5\end{array}$ & $\begin{array}{l}94 \\
80 \\
53\end{array}$ & $\begin{array}{l}94 \\
79 \\
55\end{array}$ \\
\hline \multicolumn{2}{|c|}{$\begin{array}{l}\text { 予後因子 : } \\
\text { (1)年齢 }>60 \text { 歳 } \\
\text { (2)血清LDH值 }>\text { 正常 } \\
\text { (3)Performance status }>1 \\
\text { (4)臨床病期 : II } \cdot \text { IV期 } \\
\text { (5節外病变数 } \geq \text { ? }\end{array}$} & \multicolumn{2}{|c|}{$\begin{array}{l}60 \text { 歳以下の症例 } \\
\text { (1)血清LDH值 }>\text { 正常 } \\
\text { (2)Performance status }>1 \\
\text { (3)臨床病期 : II } \cdot \text { IV期 }\end{array}$} \\
\hline
\end{tabular}

$\operatorname{dex}(\mathrm{IPI})$ である8).これは全生存率に及ぼす独 立した 5 つの予後因子：年齢, 臨床病期, Performance status, 血清LDH值, 節外病変数 (年歯令 60 歳以下の場合は年歯令, 節外病変数を除く 3 因子) を組み合わせたscoring systemであり,4つのrisk groupに分けるものである.これらの 5 年生存率 をみるとLow risk：87\%, Low/Intermediate risk : 51\%, High/Intermediate risk : 43\%, High risk： $26 \%$ となり, 4 群の予後が明確に層別化さ れた。しかしIPIはその設定時, CHOP療法 (cyclophosphamide, doxorubicin, vincristine, prednizoloneの 4 剂併用), またはCHOP類似療法を施 行された中高悪性度NHLを対象に得られた臨床 データに基づき作成されたものであり，CD20 に対するキメラ型モノクロナール抗体（rituximab) がB細胞性NHLの治療薬として導入され同 薬を含む化学療法R-CHOPのCHOPに対する優位 性が証明された現在, 外的要因である治療の変 化が予後因子に及ぼす影響を検証する必要があっ た. 2007 年Sehnらは ${ }^{9)} \mathrm{R}-\mathrm{CHOP}$ 療法を受けた 365 名のDLBCL例に関して後ろ向きに解析した結果, OS, Progression-free survival (PFS) 双方にお
いて当初のように 4 リスク群を明確には層別化 できず, very good, good, poorと 3 リスク群に 分別し得た (R-IPI) (表 4) (図 2). 分子レベルに おいてもCHOP世代で言われていた予後不良因子 であるBcl-2の過剩発現や予後良好因子であるBcl6 の発現はR-CHOP世代となって予後因子として の有用性が否定されている.

臨床データに基づく予後因子とは別に, 近年 では腫瘍細胞の生物学的特徵の視点から予後解 析を行う仕事が特にDLBCLにおいて多大なる進 歩を遂げている. RosenwaltらのグループはDNA microarrayの手法を用いてGene Expression Profiling (GEP) を行い, DLBCLを 3 つのgenotypeに分類した ${ }^{10)}$. 詳細は省略するが, この内GCB (germinal center B-cell) タイプはABC(activated B-cell）タイプに比して 5 年生存率が有意に優れ ていた $(60 \% \mathrm{vs} 35 \%$ : P<0.001).これらの知見 を基に現在臨床の場では, GEPより数段簡潔的 な免疫組織学的手法によるアルゴリズムで DLBCLをGCBタイプとABCタイプに分類してい $る^{11)}$.

一方, 前述した如くIPIはaggressive lym- 


\section{トピックス}

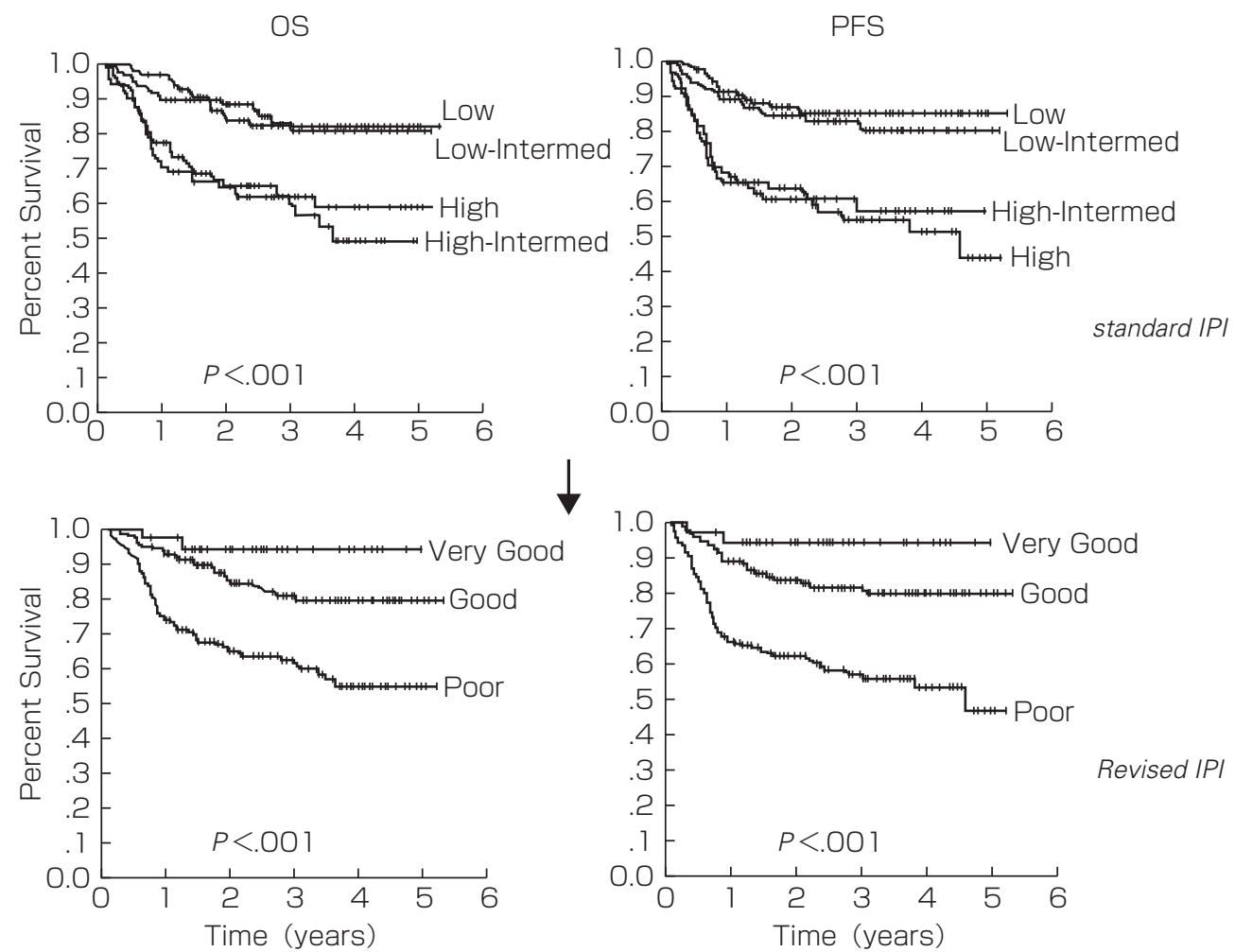

図 2. R-CHOP療法を受けたDiffuse large B cell lymphoma（DLBCL）症例における standerd International Prognostic Index (IPI) とRevised IPIによる生存率解析結果の差 異 (文献 9 より一部改変)

上段コラム : standard IPIによる生存率, 下段コラム : Revised IPIによる生存率, 左側コラム Overall survival (OS), 右側コラム : Progression-free survival (PFS) を示す.

phomaに関する予後因子であり，NHLの中でも indolent lymphomaに対してこれを単純に当て嵌 めることには無理があった. 2004 年, B細胞性indolent lymphomaの代表的疾患であるFollicular lymphoma (FL) の予後予測システムとしてFollicular lymphoma International Prognostic In$\operatorname{dex}(F L I P I)$ が提唱された ${ }^{12}$. これは 5 つの因 子 : 年齢, 臨床病期, ヘモグロビン值, リンパ 節病変数, 血清LDHから構成され, Low, Intermediate, High と 3 つのrisk群に分類されるもの である. 5 年OS, 10 年OSに関して 3 群は明確に 層別化され，その臨床的有用性を示した（表 51，5-2)(図 3).しかしIPIと同様にFLIPIはOS をend pointとしてデザインされたものであり, 設定時対象とした患者の治療背景が一定では無 く, rituximabを加えた化学療法により進行期FL の予後が明らかに改善を示している現状をより 明確に反映する予後予測システムが求められて いる.これに答えるように最近提唱されたもの がFLIPI2 である. Federicoらは ${ }^{13)}$ rituximab導入 後の 2003 年から 2005 年の間に新規滤胞性リン パ腫と診断された患者 1,093 人を対象に前向きの 解析を行いPFSをend pointとして 5 つの独立し た因子（年齢, へモグロビン值, 最大リンパ節 病変の長径, 骨髄浸潤の有無, 血清 $\beta 2$ microglobulin）を抽出した。これらに基づき 3 
表 5-1. FLIPIとFLIPI2 との比較（文献 12, 13 より改変）

\begin{tabular}{|c|c|c|}
\hline & FLIPI & FLIPIC \\
\hline 予後因子 & $\begin{array}{l}\text { (1)年齢 }>60 \text { 歳 } \\
\text { (2)病期 : IIまたは } \mathbb{I} \\
\text { (3)へモグロビン濃度 }<12 \mathrm{~g} / \mathrm{dl} \\
\text { (4)血清LDH } \mathrm{L} \text { 正常値 } \\
\text { (5)リンパ節領域数 }>4 \text { ヶ所 }\end{array}$ & $\begin{array}{l}\text { (1)血清 } \beta 2 M G \text { 值 }>\text { 正常上限 } \\
\text { (2)節性病変の最大径 }>6 \mathrm{~cm} \\
\text { (3)へモグロビン濃度 }<12 \mathrm{~g} / \mathrm{dl} \\
\text { (4)骨髄浸潤あり } \\
\text { (5)年齢 }>60 \text { 歳 }\end{array}$ \\
\hline \multicolumn{2}{|c|}{ Risk分類（FLIPI，FLIPI2 とも） } & 該当する予後因子の数 \\
\hline \multicolumn{2}{|c|}{ Low } & $0 \sim 1$ 項目 \\
\hline \multicolumn{2}{|c|}{ Intermediate } & 2 項目 \\
\hline \multicolumn{2}{|l|}{ High } & 3 項目以上 \\
\hline
\end{tabular}

表 5-2. FLIPI とFLIPI2 との比較（続き）(文献 12, 13 より改変）

\begin{tabular}{l|c|c|l|c}
\hline \multicolumn{3}{c|}{ FLIPI } & \multicolumn{2}{c}{ FLIPI2 } \\
\hline \multicolumn{1}{c|}{ Risk分類 } & 5 年OS (\%) & 10 年OS (\%) & Risk分類 & 5 年PFS (\%) \\
\hline Low & 90.6 & 70.7 & Low & 79.5 \\
Intermediate & 77.6 & 50.9 & Intermediate & 51.0 \\
High & 52.5 & 35.5 & High & 18.8 \\
\hline
\end{tabular}

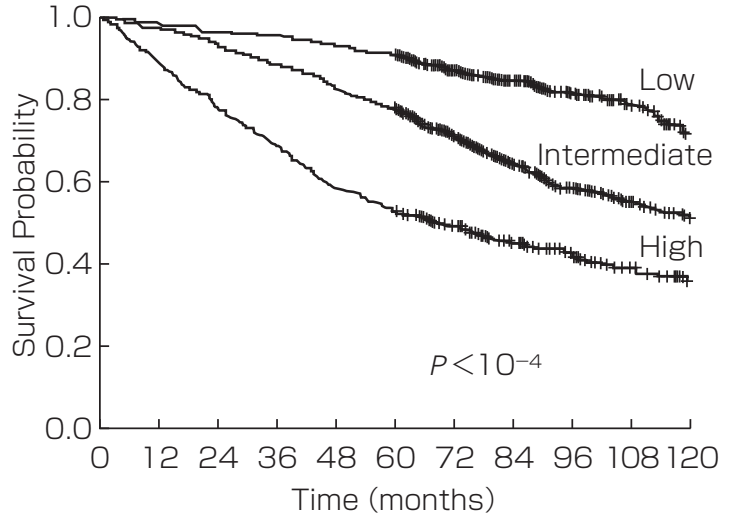

図 3. Follicular lymphoma (FL) 症例のFollicular Iymphoma International Prognostic Index (FLIPI) によるrisk群別Overall survival (OS)（文献 12 より)

つのrisk群に分類したところ,それぞれの予後が 明確に層別化できた(表 5-1，5-2）（図 4)。しか しFLIPI2 の有用性ついては現在のところ確固た るものではなく, 今後さらに検証される必要が

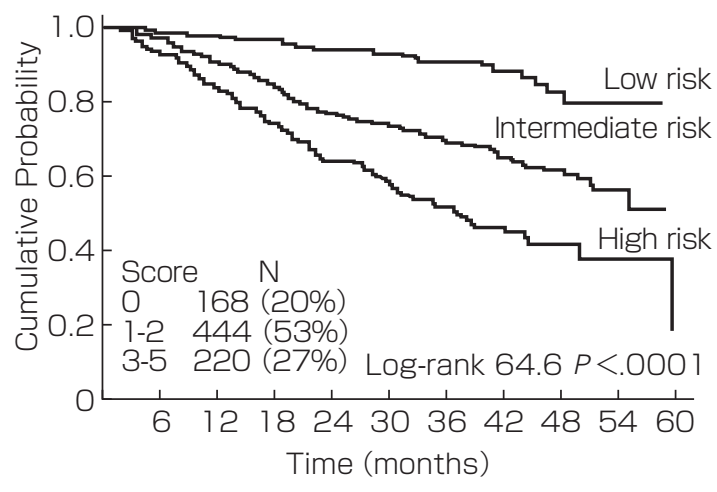

図 4. FL症例のFLIPI2 によるrisk群別Progression-free survival (PFS) (文献 13 より)

ある。

DLBCLと同様に, FLにおいても染色体, 分子 レベルでの予後因子の解析が精力的に行われて いる．例えばFLはt（14；18）転座によるBCL2 の過剩発現がbiomarkerとして有名であるが, 平 均 4 6 種の異なる染色体異常を随伴すると言わ 


\section{トピックス}

表 6. FLにおける腫瘍細胞周辺に存在する免疫応答細胞と予後との関係(文 献 16 より改変)

\begin{tabular}{c|l|l|c}
\hline & \multicolumn{1}{|c}{ 疫応答細胞 } & \multicolumn{1}{|c|}{ 発現遺伝子profile } & 予後 \\
\hline IR-1 & $\begin{array}{l}\text { T-cell/ } \\
\text { macrophages }\end{array}$ & $\begin{array}{l}\text { CD7, CD8B 1, ITK, LEF 1, STAT4, } \\
\text { ACTN 1, TNFSF3B等 }\end{array}$ & 良好 \\
\hline IR-2 & $\begin{array}{l}\text { macrophages/ } \\
\text { dendritic cell }\end{array}$ & $\begin{array}{l}\text { TLR5, FCGR1A, SEPT1 10 } \\
\text { CCR1, LGMN, C3AR1 等 }\end{array}$ & 不良 \\
\hline
\end{tabular}

IR-1: immune-response 1, IR-2: immune-response 2

表 7. 進行期Hodgkin lymphomaにおけるIPSとその予後（文献 18 より改変）

\begin{tabular}{|c|c|c|c|}
\hline 予後因子 & $\begin{array}{l}\text { 予後因子数 } \\
\text { (スコアー) }\end{array}$ & 5 年FFP* (\%) & 5 年OS（\%) \\
\hline \multirow{6}{*}{$\begin{array}{l}\text { (1)血清アルブミン值 : } 4.0 \mathrm{~g} / \mathrm{d} \text { IL下 } \\
\text { (2)へモグロビン值 : } 10.5 \mathrm{~g} / \mathrm{dl} \text { 以下 } \\
\text { (3)男性 } \\
\text { (4)臨床病期 : IV期 } \\
\text { (5)白血球数 : } 15,000 / \mu 1 \text { 以上 } \\
\text { (6)リンパ球数 : } 600 / \mu 1 \text { 以下, } \\
\text { または白血球分画の } 8 \% \text { 以下 }\end{array}$} & $\frac{0}{0}$ & 84 & 89 \\
\hline & 1 & 77 & 90 \\
\hline & 2 & 67 & 81 \\
\hline & 3 & 60 & 78 \\
\hline & 4 & 51 & 61 \\
\hline & 5 以上 & 42 & 56 \\
\hline
\end{tabular}

FFP*: Freedom from progression

れている. その中でも 6q-は, ゲノムレベルの解 析による報告を含む様々の報告のなかで共通し て挙げられている予後不良な染色体異常であ る $^{14,15)}$. 興味深い事に近年では, 腫瘍細胞側の因 子よりむしろ宿主側の因子, 特に腫瘍細胞を取 り巻く微小環境の免疫状態と予後との密接な関 係が論じられている. DaveらはFL191 症例の凍 結リンパ節検体（whole-section）を用いてGEP 解析を行ったところ, DLBCLのような腫瘍細胞 それ自体ではなく, 腫瘍周辺に存在する免疫応 答細胞が示す遺伝子発現パターンと予後とが密 接に関係することを発見した ${ }^{16)}$. すなわちT-cell, macrophageにその発現が認められる遺伝子発現 パターンを示した群：Immune-response1 は予後 良好であり，macrophageやdendritic cellにその 発現が認められる遺伝子発現パターンを示した 群 : Immune-response 2 は予後が不良であった (表 6).これら腫瘍細胞周辺に浸潤した免疫応答
細胞の種類, すなわち局在免疫環境の問題は解 析方法の難易性, 再現性から現在のところ直ち に臨床応用されるものではないが，リンパ腫治 療と密接に関係しているのみならず, 腫瘍細胞 の内的変化である悪性度の転換にも影響を及ぼ す可能性が考えられ, 予後因子を研究する上で 非常に重要である。

ここ数年, 予後不良なNHLとして注意が喚起 されているものにDouble-Hit（DH）lymphoma の存在がある. DL lymphomaとは, Burkitt Lymphoma (BL) で有名な転写因子MYCが関与する 染色体 8q24 の切断・転座に加えて, 別の遺伝子 転座が認められるNHLの一群である. 詳細はAukemaらの総説にゆずるが17)，FLに認められる BCL2 の転座やDLBCLの一部に認められるBLC6 の転座を伴うことが多く, 2008 年のWHO分類上 "B cell lymphoma unclassifiable with features intermediate between DLBCL and BL”の一部を 

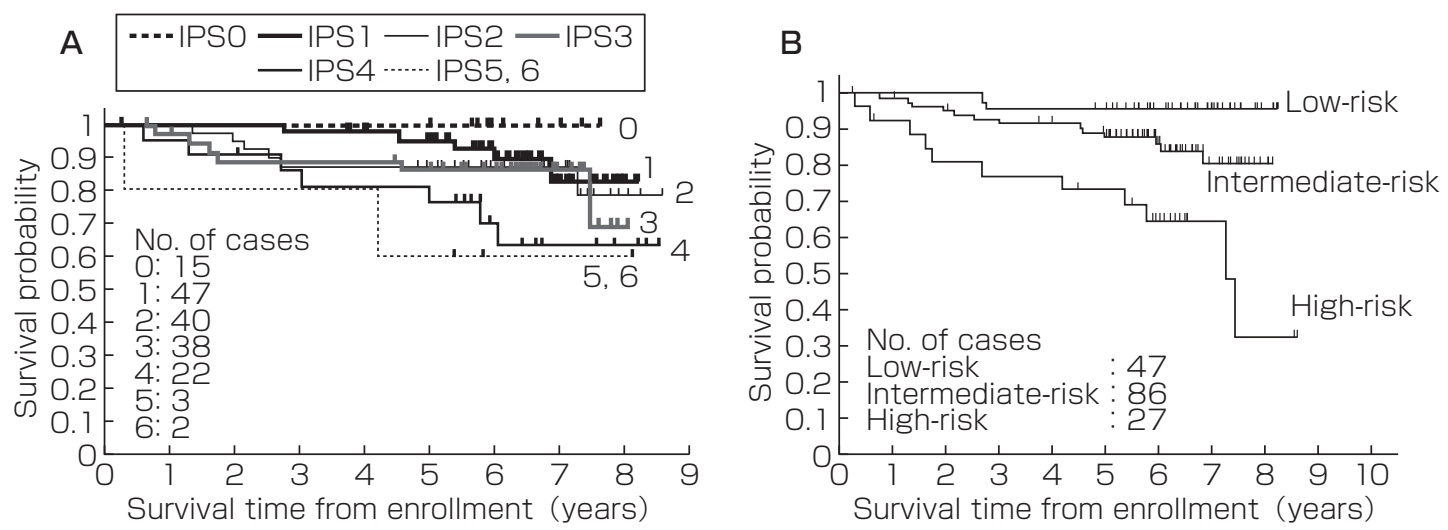

図 5. 我が国における進行期Hodgkin lymphoma（HL）の予後（文献 19 より一部改変）

A : 従来の International Prognostic Score (IPS) によるscore別Overall survival (OS)

B：2 つの予後因子（男性, 血清LDH高值）の組み合わせによる新たなrisk分類別OS.

Low risk：予後因子 0, Intermediate-risk：予後因子 1, High-risk：予後因子2 をそれぞれ有する.

構成する疾患群と考えられている。高齢発症, 中枢神経系を始めとした節外病変を伴うことが 多く,その予後はR-CHOPやその他の強力な多剂 併用化学療法を施行しても全生存期間中央值が $0.2 \sim 1.5$ 年と極めて不良である.

これまでNHLについて述べてきたが, HLに関 して, 特に進行期HLの予後因子と予後予測モデ ルについてはInternational Prognostic Score (IPS)が現在臨床の場で用いられている ${ }^{18)}$ (表 7). 但しIPSでは治療戦略上非常に重要となるvery high risk群（score 5 以上）が 7\% しか含まれず 5 年OSも $56 \%$ となっており, 真のvery high risk 群を同定できていない可能性がある. 加えて我 が国の悪性リンパ腫全体に占めるHLの割合は $4.4 \%$ と欧米に比べて低く, その発症率に地域差 があることからも,我が国のHLに対するIPSの有 用性を検証する必要があった，最近Japan Clinical Oncology Group-Lymphoma Study Group (JCOG-LSG) は 15〜69 歳の進行期HL167 例を対 象にIPSを検証したところ ${ }^{19)}$, OSに関してIPS score 1，2，3 群を明確に層別化できず，更には score 5 以上を示した患者群はわずか $3 \%$ を占め るのみでやはり 6 年OSが $60 \%$ と very high risk
群を同定できずに終わった(図 5-A)。このため 彼らは新たにmultivariate解析により男性, 血清 $\mathrm{LDH}$ 高值の 2 予後因子を抽出, 新たなscoring systemを提唱している (図 5-B). 今後更なる検 証が待たれる.

\section{3. 多発性骨髄腫}

1975 年, DurieとSalmonが 6 つの臨床上のパ ラメーター：M-タンパクの量, ヘモグロビン值, 血清カルシウム值, 骨病変の数, 血清クレアチ ニン值の組み合わせから数学的手法により腫瘍 量を推定,これにより staging systemを作成して いらい20), この臨床病期分類が予後予測としても 臨床の場で長らく用いられてきた。しかし単純 骨X線撮影による骨病変数の確認などは客観性を 欠きがちであり, 客観性に富む強力な予後因子 を組み合わせた新たな予測システムの構築が期 待されてきた.

2005年になり International Myeloma Working Groupは 10,750 名の未治療骨髄腫患者の臨床デー 夕を収集し, multivariate解析によって血清 $\beta 2$ microglobulinとalbuminを抽出, この独立した 2 
表 8. 多発性骨䯣腫におけるISS（文献 21 より改変）

\begin{tabular}{c|l|c}
\hline stage & \multicolumn{1}{|c}{ 基準 } & 生存期間中央值 \\
\hline I & $\begin{array}{l}\text { 血清 } \beta 2 \text {-microglobulin<3.5 mg/l } \\
\text { 血清albumin } \geqq 3.5 \mathrm{~g} / \mathrm{dl}\end{array}$ & 62 力月 \\
\hline I & stage I , IIの基準を満たさない & 42 力月 \\
\hline II & 血清 $\beta 2-m i c r o g l o b u l i n \geqq 5.5 \mathrm{mg} / /$ & 29 力月 \\
\hline
\end{tabular}

表 9. 骨䯣腫における染色体異常と予後との関係（文献 22 より改変）

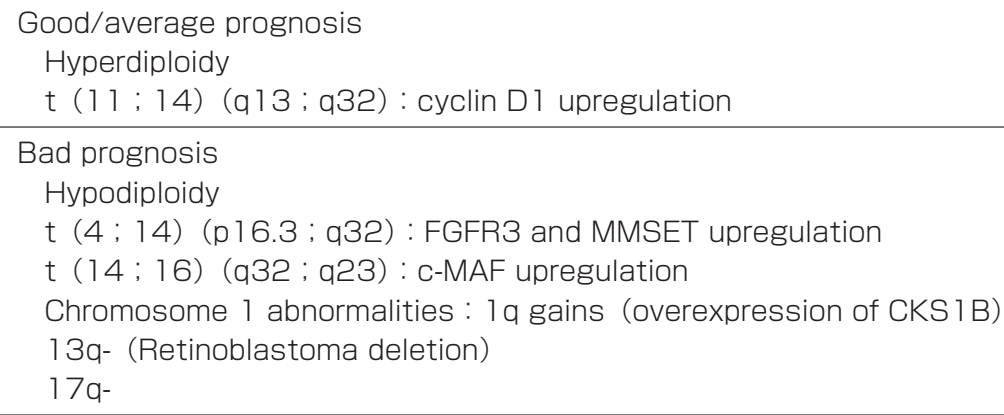

つの予後因子の組み合わせでstaging systemを作 成, International Staging System（ISS）として 発表した ${ }^{21)}$. ISSではstage I, stage II, stage III と 3 つの risk groupに分類される. それぞれの生 存期間中央值は $62,44,29$ 力月を示し, 3 group の予後は明確に階層化された (表 8). ISS分類の 卓越している点は, 年齢, 地域性（北米, ヨー ロッパ,アジア地域), 治療のタイプ(標準治療, 自家幹細胞移植術）を越えて再現性を示したこ とである. 臨床応用において簡便さの点からも ISS stage分類は優れたものであるが, Thalidmide, LenalidomideやBortezomibを用いた近年 の新しい治療体系が骨髄腫の予後に及ぼす変化 をISSが充分にカバーできるか否かは評価中であ り, また原著では染色体異常とISSとの相関は否 定されているが, それ以外の腫瘍細胞の生物学 的特徵が与えるインパクトも再検証する必要が ある.これまでに言われている染色体異常と予 後の関係 ${ }^{22)}$ を(表 9）に示す.
最近Barlogieらはmicroarrayを用いて骨髄腫 細胞のGEP解析を行い疾患関連死に関与する 70 の遺伝子を抽出した ${ }^{23)}$. これらの内 51 の遺伝子 は過剩発現, 残り 15 は過少発現を示しており, 興味深いことに過剩発現群の大半は染色体 $1 \mathrm{q}$ 上に, 過少発現群は $1 \mathrm{p}$ 上に位置していた. 過剩 発現群, 過少発現群それぞれの平均発現レベル の比をパラメーター（GEP risk score）に用いて high risk, low riskの 2 群に分け, 181 人の骨髄 腫患者のOS, EFSを調べるとhigh risk群はrow risk群に比べて両者とも有意に劣ることが判った. 更には 51 名の再発例についてGEP risk score を再発後生存率で調べたところ, 診断時/再発時 とも low risk scoreを示した群は予後良好, 診断 時/再発時とも high risk scoreを示した群は予後 不良, 診断時low risk/再発時high risk scoreを示 した群は中間の予後を示し, 再発後の予後をも 反映することが判明した，後に彼らはtandem の自家幹細胞移植術, bortezomib, thalidomide 
を含む各種治療を受けた 612 名の骨髄腫患者に ついて各種臨床検査值, 染色体分析, ISS, そし てGEP risk scoreに関するデー夕を解析, これら の予後に与えるインパクトに関して包括的な検 討を行った ${ }^{24)}$. 結果, multivariate解析で抽出で きたOS, EFS, Complete Response duration (CRD)すべてを満たす独立した予後不良因子は ISS stage III，染色体異常(異常の型は問わず), そしてGEP high riskであった. またISS各stage 内でのGEP risk分類の予後に与える影響を見る と, ISSのいずれのstageにおいても GEP high risk 群はLow risk群に比してOS, EFS, CRDともに 有意に劣っていた.このように染色体 1 番に位 置する特定遺伝子群の発現量の増減は骨髄腫の 強力な予後因子となり得そうであるが, 解析の 煩雑性, コストの面から GEP risk scoreを直ちに 臨床応用することは困難である。彼らのデー夕 を基に更に洗練された迅速かつ安価な解析法の 開発が待たれる。

\section{おわりに}

本稿ではリンパ球系腫瘍の内で幾つかの代表 的疾患を取り上げてそれらの予後について論じ てきたが，これらに関してだけでも予後因子は 多彩であり，最近の知見を網羅しょうとすれば 枚挙にいとまがない.更にここ 10 年間での外的 要因 $=$ 治療の進歩により予後解析の結果は変化 を続けている．臨床データに基づく予後因子の 種類は従来提唱されてきたものと劇的に変化し ていないのに反して, 腫瘍細胞の生物学的特徵 を反映すると考えられる遺伝子レベルで解析し た予後因子は数的にも組み合わせの面からも多 様性を増しており, 複雑化しているのが現状で ある.これは, 年齢やPS, 貧血の程度といった 臨床から得られたパラメーターが宿主側の因子 と腫瘍側因子とを包括した形で具現化された, いわば根源的な因子であり，それらの組み合わ
せの妙が発展されることはあっても, 例えば宿 主の免疫状態を客観的かつ定量的に表示できる 臨床検査法などが開発されない限り今後新規な 因子が発見される可能性は少ない。一方腫瘍が ゲノムレベルでのmulti-hitにより成立することを 考えると, 複数の遺伝子の異常が密接に関連し 合って予後を規定することは明白である．よっ て必然的にkeyとなる遺伝子異常の抽出と, それ らの組み合わせ, グループ化が重要となる。こ の点で腫瘍細胞のGene expression profilingなど の網羅的解析法はその空口を開く非常に有効な 手段である。しかしこれらのアプローチにも問 題はある. 腫瘍の悪性度は細胞内分子の機能的 変化に依存している. 分子の発現レベルの変化 はその一側面を見ているのに過ぎない。むしろ 重要なのはリン酸化, アセチル化, ユビキチン 化といった翻訳後修飾の状態の変化である.こ れらの変化を俯瞰できるような手段ができれば, 今後予後因子解析は飛躍的に発展するであろう. 最後に腫瘍の予後因子解析はNever-EndingStoryといえる.

著者のCOI (conflicts of interest) 開示: 本論文発表内容に 関連して特に申告なし

\section{文献}

1) Rowe JM : Prognostic factors in adult acute lymphoblastic leukaemia. Br J Haematol 50 : 389-405, 2010.

2) Takeuchi J, et al : Induction therapy by frequent administration of doxorubicin with four other drugs, followed by intensive consolidation and maintenance therapy for adult acute lymphoblastic leukemia : the JALSG-ALL93 study. Leukemia 16 : 1259-1266, 2002.

3) Hatta Y, et al : Promising outcome of Imatinib-combined chemotherapy followed by allogeneic hematopoietic stem cell transplantation for Philadelphia chromosomepositive acute lymphoblastic leukemia : results of the Japan Adult Leukemia Study Group (JALSG) Ph + ALL 202 regimen[abstract]. Blood 114 : 1201, Abstract 3090. 2009

4) Rowe JM, et al : Induction therapy for adults with acute lymphoblastic leukemia : results of more than 1500 patients from the internationalALL trial:MRC UKALLXII/ 
ECOG E2993. Blood 106 : 3760-3767, 2005.

5) Moorman AV, et al : Karyotype is an independent prognostic factor in adult acute lymphoblastic leukemia (ALL) :analysis of cytogenetic data from patients treated on the Medical Research Council (MRC) UKALLXII/ Eastern Cooperative Oncology Group (ECOG) 2993 trial. Blood 109 : 3189-3197, 2007.

6) Kuhnl A, et al:High BAALC expression predicts chemoresistance in adult B-precursor acute lymphoblastic leukemia. Blood 115 : 3737-3744, 2010.

7) Mansour MR, et al : Prognostic implications of NOTCH1 and FBXW7 mutations in adults with T-cell acute lymphoblastic leukemia treated on the MRC UKALLXII/ ECOG E2993 protocol. J Clin Oncol 27 : 4352-4356, 2009.

8) Project TIN-HsLPF : A predictive model for aggressive non-Hodgkin's lymphoma. The International NonHodgkin's Lymphoma Prognostic Factors Project. N Engl J Med 329 : 987-994, 1993.

9) Sehn LH, et al : The revised International Prognostic In$\operatorname{dex}(\mathrm{R}-\mathrm{IPI})$ is a better predictor of outcome than the standard IPI for patients with diffuse large B-cell lymphoma treated with RCHOP. Blood 109 : 1857-1861, 2007.

10) Rosenwald A, et al : The use of molecular profiling to predict survival after chemotherapy for diffuse large-B-cell lymphoma. N Engl J Med 346 : 1937-1947, 2002.

11) Choi WW, et al: A new immunostain algorithm classifies diffuse large B-cell lymphoma into molecular subtypes with high accuracy. Clin Cancer Res 15 : 5494-5502, 2009.

12) Solal-Celigny $P$, et al: Follicular Lymphoma International Prognostic Index. Blood 104 : 1258-1265, 2004.

13) Federico $M$, et al: Follicular lymphoma international prognostic index 2 : a new prognostic index for follicular lymphoma developed by the international follicular lymphoma prognostic factor project. J Clin Oncol 27 : 45554562, 2009 .

14) Tilly $\mathrm{H}$, et al : Prognostic value of chromosomal abnor- malities in follicular lymphoma. Blood 84: 1043-1049, 1994.

15) Cheung KJ, et al : Genomewide profiling of follicular lymphoma by array comparative genomic hybridization reveals prognostically significant DNA copy number imbalances. Blood 113: 137-148, 2009.

16) Dave SS, et al: Prediction of survival in follicular lymphoma based on molecular features of tumor-infiltrating immune cells. N Engl J Med 351 : 2159-2169, 2004.

17) Aukema SM, et alDouble hit B-cell lymphoma. Blood Prepublished online nov 30, 2010; doi:10.1182/blood-201009-297879.

18) Hasenclever D, Diehl V:A prognostic score for advanced Hodgkin's disease. N Engl J Med 339 : 1506-1514, 1998.

19) Itoh $K$, et al: Prognostic analysis and a new risk model for Hodgkin lymphoma in Japan. Int J Hematol 91 : 446455, 2010.

20) Durie BGM, et al : A clinical staging system for multiple myeloma. Correlation of myeloma cell mass with presenting clinical features, response to treatment, and survival. Cancer 36 : 842-854, 1975.

21) Greipp PR, et al : International staging system for multiple myeloma. J Clin Oncol 23 : 3412-3420, 2005.

22) Bladé J, et al : Prognostic factors for multiple myeloma in the era of novel agents. Ann Oncol 19 (Suppl 7) : viil17vii120, 2008.

23) Shaughnessy JD, et al : A validated expression signature of high-risk multiple myeloma is defined by dysregulated expression of genes mapping to chromosome 1 . Blood 109 : 2276-2284, 2007.

24) Waheed S, et al: International Staging System and Metaphase Cytogenetic Abnormalities in the Era of Gene Expression Profiling Data in Multiple Myeloma Treated With Total Therapy 2 and 3 Protocols. Cancer Oct 13: 19,2010 . 